\title{
Return on Investment in Tertiary Education and Tuition Policy in Vietnam
}

\author{
PHÙNG XUÂN NHẠ \\ Associate Professor, Doctor of Philosophy, Hà Nội National University \\ Email:nhapx@vnu.edu.vn \\ PHẠM XUÂN HOAN \\ Doctor of Philosophy, Insurance Research and Training Center - Ministry of Finance \\ Email: hoanphamxuan@gmail.com
}

\begin{abstract}
This research estimates the return on investment in tertiary education in Vietnam by quantifying and comparing total economic benefit with total incurred cost of tertiary education. Conclusion is that an individual can gain VND324.46 from an investment of VND100 in tertiary education that helps improve his/her productivity. The return on investment in tertiary education equals a positive real rate of interest of $3.15 \%$ for an individual learner and 2.9\% for society. Increases in tuition as directed by Decree 49/2010/CP-CP for the years 2011-2015 and as suggested by Phùng \& Pham (2012) for 2016-2020 do not make investment in tertiary education less attractive in comparison with that in capital market. The research suggests reform in tertiary education in which time for study is reduced and financial investment in terms of tuition is increased.
\end{abstract}

Keywords: cost of education, benefit from education, return on investment, tuition reform 


\section{INTRODUCTION}

Education is a special field. It can be seen as a basic right for citizens who can free themselves from illiteracy and gain a full knowledge to enjoy their lives. Moreover, education is also a form of investment in human resources to improve labor productivity.

When education is considered as a human basic right, the state often supports learners, especially the unprivileged, which reflects a humanistic aspect of the society. When education is treated as an investment, it is reasonable to charge some tuition fees in order to ensure quality of education service and reduce governmental subsidies.

Determining how large governmental subsidies and tuition fees should be is a difficult and sensitive issue. Foreign experience offers various lessons, and Vietnam could not simply copy a model.

In principle, determining a reasonable level of tuition requires exact calculations of benefits ensured by education service for learners. Besides economic benefits, such as future pay corresponding to paid tuitions, there are non-economic ones, such as ability to enjoy information, literature and arts; socialize and gain respect from others, etc. However, there has been no quantitative research on non-economic benefits from education, and all studies are about economic ones.

One method of measures of benefits from education that has been widely studied and acknowledged is the return on investment in education. A few dozen studies of this measure are summarized by Psacharopoulos \& Patrinos (2002). As for Vietnam, researches on the measure can be found in Patrinos \& Moock (1998); VHLSS (1993, 2004), and ADB (2012), etc.

In nature, return on investment in tertiary education of $r \%$ (10\% for example) means that each year of tertiary education makes average pay for learners after graduation increase by $r \%$ in comparison with people who have no tertiary education. If this return is high, education service is considered to be effective; and more investment in this service is advisable, and vice versa.

The importance of this return on investment in tertiary education, however, is limited, and may be misled because a return of $10 \%$ usually makes us think that investors can annually gain 10 dollars from an investment of 100 dollars. In other words, we might understand that the monetary return on investment in tertiary education is $10 \%$. 
That is not true. Let us examine two education services with the same return on investment of $10 \%$. If the first education service suffers higher costs while the average wage is lower than the second one, the real efficiency of the first education service is lower than the second one. Why? When calculating return on investment, researchers only pay attention to time of study without quantifying it in terms of money, or costs. Similarly, they only calculate increases in income as benefits from education without quantifying them in terms of money. To deal with this shortcoming, researchers employ regression method with support from specialized software to quantify all costs while this measure still has the aforementioned applications.

This research tries to estimate more exactly the return on investment in tertiary education in Vietnam by quantifying and comparing total economic benefit [1] from education with total incurred cost of tertiary education. More specifically, the research is to answer two questions: (1) How much money can be gained from each dollar invested in tertiary education by higher productivity in the future? and (2) What equivalent to real rate of interest on the capital market can investment in tertiary education produce every year (after inflation rate is deducted)? Based on the two answers, the research deals with the third one: Do increases in tuition as directed by Decree 49/2010/CP-CP for the years 2011-2015 and as suggested by Phùng \& Phạm (2012) for 2016-2020 make investment in tertiary education less attractive than that in the capital market?

Table 1: Classification of Costs of Education

\begin{tabular}{|l|l|l|l|}
\hline \multicolumn{2}{|l|}{ Social cost of education } & $\begin{array}{l}\text { Governmental } \\
\text { education } \\
\text { subsidies }\end{array}$ & $\begin{array}{l}\text { Non-tuition } \\
\text { sources of } \\
\text { income for } \\
\text { schools used for } \\
\text { education } \\
\text { Learners' financial cost }\end{array}$ \\
\cline { 1 - 2 } & $\begin{array}{l}\text { Learners' } \\
\text { opportunity cost } \\
\text { Ton-tuition expenditures: (1) } \\
\text { contributions to schools, (2) text } \\
\text { books, (3) learning tools, (4) } \\
\text { uniform, and (5) others }\end{array}$ & $\begin{array}{l}\text { Income lost due } \\
\text { to leaving } \\
\text { workplace for } \\
\text { school }\end{array}$ & \\
\hline
\end{tabular}

Source: Authors' illustration 


\section{THEORETICAL BASIS AND METHODOLOGY}

The research assumes that school age starts at six, and people finish primary education at ten. If they keep learning, they will finish lower secondary, upper secondary, vocational and tertiary education at 14, 17, 20 or 22 respectively as shown in Figure 1.

Table 1 shows that in studying years learners should cover various costs, namely, tuition and five non-tuition expenditures [2] and opportunity cost of schooling. Regarding social costs, there are governmental subsidies and other expenditures on education covered by non-tuition sources of income.

GSO reports always provide data about working population of 15 years of age and older. This research, therefore, assumes that the working age of a person with only primary or lower secondary education, or without any education, starts at 15 . Thus, primary or lower secondary education implies no opportunity cost because at this age, learners are too young to join the working population and gain some income.

When attending vocational schools and universities, learners face opportunity costs. Specifically, opportunity cost is incurred in three years (from 18 to 22 years of age) and equals annual income for a worker with upper secondary education. Similarly, learners incur opportunity cost of tertiary education in five years, from 18 to 22 years of age. This cost equals annual income for a worker with upper secondary education.

Benefits gained in working years

$$
\text { Return on investment }=\frac{\text { Financial cost }+ \text { Opportunity cost }}{\text { (of vocational and tertiary education) }}
$$

Regarding benefits as shown in Figure 1, persons who graduate primary, secondary, and vocational schools, or universities and colleges may acquire higher income during their working life of 46, 46, 43, 40 and 38 years respectively.

As presented in Section 1, we estimate return on investment in each level of education using two indexes. Firstly, ratio of total benefits gained during working years (due to higher pay) to total costs incurred in learning years. 


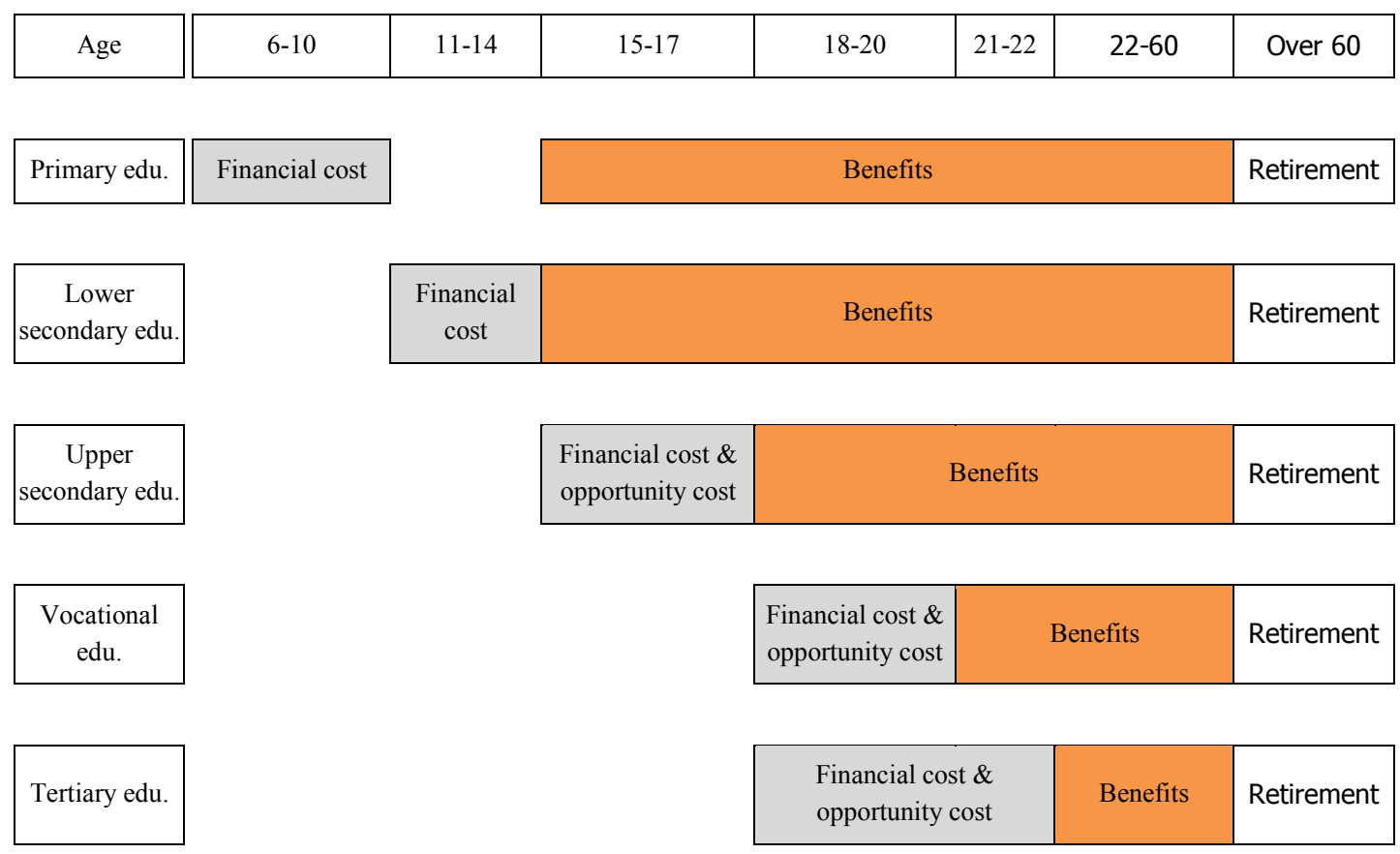

Figure 1: Illustration of Costs and Benefits of Education

Source: Authors' assumptions, 2012

Calculating the total benefits gained during working years [numerator of fraction (1)] and opportunity cost of learning years [denominator of fraction (1)] is based on the following method:

$$
\operatorname{Ln}(x)=\alpha+\beta(\text { age })+\beta_{1}(\text { age })^{2}+\gamma D_{\text {sex }}+\varepsilon D_{\text {urban }}+\rho D_{\text {ethinicity }}+\sum_{i=1}^{8} \delta_{i} D_{i}+u(2)
$$

Regression of income (expressed in logarithm) of workers is based on age, square age, dummy variable for gender, dummy variable for living and working location, dummy variable for ethnicity, and dummy variable for education.

Equation (2) employs eight dummy variables for education of workers corresponding to eight training levels recorded by VHLSS (2008 and 2010): (i) primary education; (ii) lower secondary education; (iii) upper secondary education; (iv) short-term technical education; (v) long-term technical education; (vi) professional 
secondary education; (vii) vocational education; and (vii) tertiary education. Dummy variable $\mathrm{D}_{1}$ takes the value of 1 if the worker finishes level $i$ and 0 otherwise. Thus, coefficient $\delta_{i}$ shows ratio of wage for a worker with education $i$ to wage of a worker with no education and degree.

Suppose that a worker who has no education or training or degree gains an annual wage $\mathrm{W}_{0}$, the annual average benefit from education of level $i$ will be:

$$
\left.i=W_{0}\left(\delta_{i}-\delta_{i-1}\right)\right)
$$

And average opportunity cost for a year the worker takes training of level $i$ equals the annual average income for a worker with education of level $i-1$, or:

$$
\left.i=W_{0}\left(1+\delta_{i-1}\right)\right)
$$

Suppose that the wage for each worker reflects exactly his/her productivity, and that productivity of a worker with no education or training equals 1 , productivity of a worker with education of level $i$ will equal $(1+i)$.

\section{SHARE OF EDUCATION IN LABOR PRODUCTIVITY}

Applying regression method to equation (2) using data from VHLSS 2008, ADB (2012) produces the following table.

Table 2: Productivity-Based Human Capital in Vietnam for 15 Years and Older

\begin{tabular}{lccc}
\hline & $\begin{array}{c}\text { Total Number of } \\
\text { Persons (VND } \\
\text { million) }\end{array}$ & $\begin{array}{c}\text { Productivity } \\
\text { Weight }\end{array}$ & $\begin{array}{c}\text { Total Human } \\
\text { Capital } \\
\text { (VND million) }\end{array}$ \\
\hline No degree & 14.02 & 1.00 & 14.02 \\
Primary & 15.10 & 1.02 & 15.44 \\
Lower secondary & 18.60 & 1.09 & 20.16 \\
Upper secondary & 9.30 & 1.31 & 12.22 \\
Short-term technical & 2.20 & 1.41 & 3.15 \\
Long-term technical & 1.30 & 1.58 & 2.00 \\
Professional secondary school & 2.30 & 1.68 & 3.82 \\
Vocational college & 0.20 & 1.64 & 0.37 \\
Tertiary general & 3.50 & 2.14 & 7.46
\end{tabular}




\begin{tabular}{lccc}
\hline General education & 46.47 & 1.19 & 55.28 \\
Vocational education & 6.00 & 1.56 & 9.34 \\
Total & 66.49 & 1.18 & 78.64 \\
\hline
\end{tabular}

Source: ADB, 2012

Thus, the average productivity of a worker with tertiary education is 2.14 times higher than that of a worker with no degree. In 2008, the working population of 15 years and older was 66.49 million but the total human capital equaled 78.64 million untrained workers. The average productivity weight was 1.18 .

The weight of 1.18 comes from education and training. This weight, however, is not high because too many people (14.02 million) are not trained. Numbers of workers with low education levels are also very large: 15.1 million only finish primary education; 18.6 million lower secondary and 9.3 upper secondary education.

\section{STRUCTURE OF PERSONAL EXPENDITURE ON TERTIARY EDUCATION IN VIETNAM}

Table 3 presents personal expenditures on tertiary education without including public expenditure and spending by schools from non-tuition sources of income. These expenditures comprise tuition and five expenditures summarized by VHLSS (2010) as shown in Table 1.

Table 3: Personal Expenditure - Benefits from Higher Education (VND million)

\begin{tabular}{|c|c|c|c|c|c|c|c|}
\hline Level & Productivit & $\begin{array}{c}\text { Annual } \\
\text { financial } \\
\text { cost }\end{array}$ & $\begin{array}{l}\text { Annual } \\
\text { I average } \\
\text { income }\end{array}$ & $\begin{array}{l}\text { Opportunity } \\
\text { cost }\end{array}$ & $\begin{array}{l}\text { Total } \\
\text { cost }\end{array}$ & $\begin{array}{c}\text { Total } \\
\text { economic } \\
\text { benefit } \\
\text { during } \\
\text { working } \\
\text { years after } \\
\text { graduation }\end{array}$ & $\begin{array}{c}\text { Return on } \\
\text { investment } \\
\text { in } \\
\text { education } \\
\text { for learner }\end{array}$ \\
\hline No degree & 1.00 & 0.00 & 16.00 & 0 & 0.00 & 0.00 & na \\
\hline Primary (5 years) & 1.02 & 1.12 & 16.32 & 0 & 5.62 & 14.72 & $262.15 \%$ \\
\hline $\begin{array}{l}\text { Lower secondary ( } 4 \\
\text { years) }\end{array}$ & 1.09 & 1.52 & 17.44 & 0 & 6.08 & 51.52 & $847.93 \%$ \\
\hline Upper secondary (3 & 1.31 & 2.88 & 20.96 & 17.44 & 60.96 & 151.36 & $248.29 \%$ \\
\hline
\end{tabular}


years)

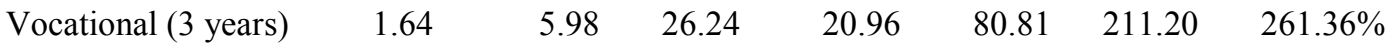

$\begin{array}{llllllll}\text { Tertiary (5 years) } & 2.14 & 10.15 & 34.24 & 20.96 & 155.53 & 504.64 & 324.46 \%\end{array}$

Source: Authors' calculations based on ADB (2012) and VHLSS (2010)

Table 4: Tuition of Tertiary Education in 2011-2015 (VND1,000/month/ student)

\begin{tabular}{lccccc}
\hline \multicolumn{1}{c}{ University } & $\begin{array}{c}\mathbf{2 0 1 0 -} \\
\mathbf{2 0 1 1}\end{array}$ & $\begin{array}{c}\mathbf{2 0 1 1 -} \\
\mathbf{2 0 1 2}\end{array}$ & $\begin{array}{c}\mathbf{2 0 1 2}- \\
\mathbf{2 0 1 3}\end{array}$ & $\begin{array}{c}\mathbf{2 0 1 3 -} \\
\mathbf{2 0 1 4}\end{array}$ & $\begin{array}{c}\mathbf{2 0 1 4}- \\
\mathbf{2 0 1 5}\end{array}$ \\
\hline $\begin{array}{l}\text { 1. Social sciences, economics, law, } \\
\text { agronomy, forestry and fishery }\end{array}$ & 290 & 355 & 420 & 485 & 550 \\
$\begin{array}{l}\text { 2. Natural sciences, technology, } \\
\text { technique, sports, arts, hospitality, } \\
\text { tourism }\end{array}$ & 310 & 395 & 480 & 565 & 650 \\
$\begin{array}{l}\text { 3. Medicine and Pharmacy } \\
\text { Average }\end{array}$ & 340 & 455 & 570 & 685 & 800 \\
\hline
\end{tabular}

Source: Decree 49/2010/CP-CP dated May 15, 2010

The second column of Table 3 shows that personal expenditures on education of low levels (primary and secondary one) are low due to generous subsidies from the government, especially for primary education. This trend is common in most countries where low levels of education aim at solving social issues and implementing rights to basic knowledge.

Concerning tertiary education such as vocational and tertiary education, economic efficiency is definitely considered as a prime target, and therefore tuition fees are relatively higher. Moreover, non-tuition expenditures are also high, making total personal financial cost increase, to VND5.98 million per year for vocational education and VND10.15 million per year for tertiary education as shown in the second column of Table 3 .

In the school year of 2010-2011, tuition for tertiary education was VND313,000 per month on average (Table 4). Thus, of the total personal financial cost of VND10.15 million a year, tuition accounts for VND3.13 million and VND7.02 million are spent on five non-tuition expenditures (Table 1). 
We can draw two important conclusions about personal financial cost of tertiary education in Vietnam:

- Tuition cost is small, representing $30.81 \%$ of total personal financial cost (VND3.13 million out of 10.15 million) and $10.01 \%$ of total personal expenditure (including opportunity cost of VND20.96 million a year).

- Personal financial cost is also very small in comparison with opportunity cost, equaling $48.43 \%$ only [3] (VND10.15 million compared with 20.96 million).

The two conclusions suggest that tuition can be increased without causing remarkable impacts on learners. They also point up a potential reform in tertiary education in which studying period can be cut and financial investment increased. If the studying period is cut by six months (after this cut, the studying period in Vietnam's universities is still long as compared with other countries, such as three years in Australia), reduction in opportunity cost can allow increases in tuition and non-tuition expenditures on tertiary education by $22.95 \%$ [4] for the whole studying period.

At present when public expenditure on tertiary education is limited while benefits from tertiary education for learners along with cuts in opportunity cost and studying period are considerable as mentioned above, increases in financial investment in tertiary education can be implemented by raising tuition fees.

Raising tuition fees is always a sensitive issue that may ignite public protests but it is very necessary when issue of efficiency is taken into consideration. Government would rather find measures to help learners cover personal expenditure on tertiary education (supply of financial aid and scholarship, or cuts in tuitions for students from poor families or depressed districts, etc.) than maintain low tuitions for a low-quality and time-wasting tertiary education.

\section{RETURN ON INVESTMENT IN TERTIARY EDUCATION}

This section analyzes financial efficiency of investment in tertiary education. The last column of Table 3 shows that return on investment in tertiary education for learners is $324.46 \%$. This implies that from an investment of 100 dollars in tertiary education, a learner may gain 324.46 dollars during 38 working years.

Let us take another example to understand the rate of $324.46 \%$. If a person deposits 100 dollars in a bank with a real rate of interest (nominal rate minus inflation rate) of 
$3.15 \%$ per year and this deposit enjoys a compound interest policy; 38 years later (equaling the working life of a university graduate) that person will receive 324.46 dollars for both principal and accrued interest. Thus, return on investment in tertiary education equals the return on a bank deposit at a real interest rate of $3.15 \%$ per year.

A positive real rate of interest of $3.15 \%$ per year is so relatively high that we can hardly meet. It may exist for a short time only, some months for example, when interest rate is raised abnormally to curb hyperinflation. Thus, investment in tertiary education is an effective investment for learners because the positive real rate of interest on capital market - for example in Japan where inflation rate is very low - is usually about $0 \%-0.5 \%$.

From a social aspect, tertiary education requires not only personal expenditures but also subsidies from the government and other spendings by schools from non-tuition sources of income. According to Thắng et al. (2012), if these additional spendings (by the government and schools) equal tuition paid by learners and calculations are done as presented in Table 3, return on investment in tertiary education will equal the return on a bank deposit at a positive real interest rate of $2.91 \%$ per year. Although this rate is lower than the $3.15 \%$ rate for learners, it is relatively higher than the real interest rate found in capital markets.

In sum, we may conclude that investment in tertiary education is productive for both learners and society. Besides economic benefits, it also produces non-economic positive effects that are beyond this research. This conclusion shows that regarding effectiveness of investment, the government can allow schools to raise tuition. However, this increase should be linked with improvements in quality of education services, and the government should establish a mechanism for supervising this relation.

\section{ANALYSIS OF POLICY ON TUITION OF TERTIARY EDUCATION IN TERMS OF RETURN ON INVESTMENT AND SUGGESTIONS}

Decree 49/2010/CP-CP dated May 15, 2010 sets increasing tuitions of tertiary education for the years 2011-2015.

Phùng \& Phạm (2012) suggest a process of raising tuition of tertiary education for the period 2016-2020 in which increases in tuition should ensure that quality of education of all universities will reach the world's medium level by 2020 (and by 2025 for universities of agriculture, forestry and fisheries). By this process, tuition by 2020 
will be 4.68 times higher than the 2011 one, and 2.2 times higher than the 2016 one. If inflation rate is taken into account, the 2020 tuition will be 2.55 times higher than the 2011 one, and 1.57 times higher than the 2016 one.

This section analyzes the process of raising tuition according to Decree 49/2010/CP-CP and presents this process from perspective of the return on investment in education. More specifically, this section will answer the third question in section 1: Does implementation of this process make investment in tertiary education less attractive than that in the capital market? In other words, is investment in education still productive?

Table 5 shows that according to the plan presented in Decree 49/2010/CP-CP, return on investment in tertiary education equals the return on a bank deposit at a positive real interest rate of $3.00 \%$ per year for learners, and $2.64 \%$ for society by 2015 (the last year of the plan).

According to the plan suggested by Phùng \& Phạm (2012), return on investment in tertiary education equals the return on a bank deposit at a positive real interest rate of $2.79 \%$ per year for learners, and $2.29 \%$ for society by 2020 (the last year of the plan).

We believe that our suggestion is not unreasonable regarding the return on financial investment. Both learners and society can gain great benefits from investment in education. In other words, investment in education is still more attractive than that in the capital market.

It is worth noting that increases in tuition are based on assumption that no change is made to studying period. This research suggests that more studies should be conducted to raise the tuition higher and make studying period shorter. To what extent such increases and cuts could be done is a problem that required more careful studies.

\section{CONCLUSION}

This research estimates the return on investment in tertiary education by comparing total benefits with total costs of tertiary education. To calculate total benefits, the authors use data on productivity weight of human resource of various training levels published by ADB (2012). To calculate the total costs, authors employ data from VHLSS 2010 published by the GSO. 
Results show that investment in tertiary education is more productive for both learners (including both financial and opportunity costs) and society than investment in capital market.

In structure of total cost of tertiary education for learners, tuition only represents a small percentage in comparison with financial cost that is also very small compared with opportunity cost incurred by learners, but tuition has the greatest effect on education quality. The tuition, therefore, should be increased to enhance the return on investment in education that is much higher than the tuition.

Examining plans to raise tuition presented by Decree 49/2010/CP-CP for the years 2011-2015 and Phùng \& Phạm (2012) for the years 2015-2020, the research demonstrates that despite such increases, both learners and society still gain greater returns on investment in tertiary education than on investment in capital market. Thus, the suggested plans for increases in tuition are highly feasible

\section{Notes}

[1] This research did not mention non-economic benefits from education, such as freedom from illiteracy and ignorance, full knowledge to enjoy their lives, and respect from others, etc.

[2] As classified by VHLSS 2010

[3] Personal financial cost only includes direct expenditures on education. Attending school also requires a huge cost of daily life. If the cost of living is included, personal financial cost may be much greater than opportunity cost.

[4] Authors' calculations from Table 3.

[5] Results presented in Table 4 do not include future increases in labor productivity when tertiary education receives more investment.

\section{References}

ADB (2012), On Measuring Human Capital: A Case Study of Vietnam

GSO (1993, 2004, 2008 and 2010), VHLSS (Vietnam Household Living Standards Survey) 1993, 2004, 2008 and 2010.

Moock, P.R., H.A. Patrinos \& M. Venkataraman (1998), Education and Earnings in a Transition Economy: The Case of Vietnam, World Bank.

Phùng Xuân Nhạ \& Phạm Xuân Hoan (2012), "Chi phí, lợi ích đầu tư cho giáo dục đại học Việt Nam và hàm ý về lộ trình cải cách học phí theo nhóm ngành”, Phát triển Kinh tế, No. 264. 
Psacharopoulos, G. \& H.A. Patrinos (2002), Returns to Investment in Education: A Further Update, World Bank Policy Research, Working paper No. 2881, Washington, D.C.

Thắng et al. (2012): Research on the Unit Cost of Education, done within the framework of the Second Higher Education Project (P079665), Component 1: Capacity Building for Policy Development, Sub-component 1.2: Financing.

Vietnamese Government (2010), Decree 49/2010/CP-CP dated May 15, 2010 on exemption and reduction in tuition, financial aid for students, collection and use tuition by schools in the national education system from 2010-2011 to 2014-2015 school years.

World Bank (2008), Vietnam: Higher Education and Skills for Growth, Human Development Department, World Bank. 